\title{
Isolation and characterization of Pyricularia oryzae isolated from lowland rice in Sarawak, Malaysian Borneo
}

\author{
Nor Ain Hussin ${ }^{1}$, Freddy Kuok San Yeo ${ }^{\star *}$, Nur Karimah Mohamad1, Nur Najwa Hamsein², Tu Anh Vu Thanh, \\ Hung Hui Chung ${ }^{1}$ and Lee San Lai ${ }^{2}$
}

\author{
${ }^{1}$ Faculty of Resource Science and Technology, Universiti Malaysia Sarawak, 94300 Kota Samarahan, Sarawak, \\ Malaysia. \\ ${ }^{2}$ Agriculture Research Centre, Semongok, $12^{\text {th }}$ Mile, Kuching-Serian Road, P.O. Box 977, 93720 Kuching, Sarawak, \\ Malaysia. \\ Email: yksfreddy@unimas.my
}

Received 4 April 2019; Received in revised form 28 June 2019; Accepted 4 July 2019

\begin{abstract}
Aims: Rice blast disease caused by Pyricularia oryzae is one of the major biotic diseases of rice in Sarawak, Malaysian Borneo. This study aims to isolate and characterize rice blast fungus obtained from infected leaf collected from four different divisions in Sarawak, viz, Miri, Serian, Sri Aman, and Kuching.

Methodology and results: Twelve succeeded isolates were pre-identified as $P$. oryzae by morphological characteristics of spores, followed by verification through (internal transcribed spacer) ITS sequencing. The isolates were evaluated for morphological characteristics, growth rate and sporulation rate, which were grown on two types of media, (filtered oatmeal agar) FOMA and (potato dextrose agar) PDA. Morphological characterization showed that the colony surface of the different isolates varied from smooth and fluffy to rough and flattened mycelia; some were with the present of concentric rings, and some with aerial mycelia. The growth rate and sporulation rate of each isolate varied based on types of media used. Most of the isolates grew faster on PDA than on FOMA but produced higher number of spores on FOMA as compared to PDA.

Conclusion, significance and impact of study: This preliminary study showed that there were variations observed based on morphological and physiological characterization for the different isolates collected in Sarawak, Malaysian Borneo. This study is the first step towards understanding variation in the population of $P$. oryzae from Sarawak.
\end{abstract}

Keywords: Pyricularia oryzae, Sarawak rice, morphological characteristics, growth rate, sporulation rate

\section{INTRODUCTION}

Rice (Oryza sativa L.) is a crucial food crop that is widely grown to feed half of the world's population. More than $90 \%$ of rice is cultivated and consumed in Asia (Khush, 2005; Talbot and Wilson, 2009; Global Rice Science Partnership, 2013). In Malaysia, the rice production caters approximately $65 \%$ of the population demands. As a result, Malaysia still depends on imported rice to meet the total demand. Rice production in Malaysia needs to be increased to reach the status of self-sufficiency and to meet the demand of the rapid growing population (Abdul Rahim et al., 2017). Increasing the rice production is always challenged by rice diseases. One of the diseases is rice blast. Rice blast is recognized as one of the major biotic stresses that could lead up to $10 \%$ and $30 \%$ significant yield losses each year, globally (Skamnioti and Gurr, 2009; Zhou, 2016;). In Malaysia, rice yield loss due to rice blast can reach up to $50 \%$ (Gianessi, 2014; Elixon et al., 2017).

Rice blast disease is caused by filamentous ascomycete fungus, Magnaporthe oryzae (T.T. Hebert) M. E. Barr (anamorph P. oryzae Sacc.) (Silva et al., 2009; Talbot and Wilson, 2009). This fungus can infect all stages of rice development and different parts of rice plants; leaves, stems, nodes and panicles (Talbot and Wilson, 2009). The lesion is typically a diamond shape with grayish center and brown margin. Under favorable conditions, the lesions can enlarge rapidly and tend to coalesce, leading to plant death (Wang et al., 2014).

Breeding blast resistant varieties is a promising method in rice blast management (Ashkani et al., 2015). However, the resistance might eventually be overcome by $P$. oryzae due to their genetic diversity and their ability to recombine (Scheuermann et al., 2012). For example, rice blast resistant cultivar MR219 (Hussain et al., 2012) in 
Peninsular Malaysia had its resistance breakdown which led to rice blast disease outbreak (Abed-Ashtiani et al., 2016). It is a constant challenge for breeders in Peninsular Malaysia to breed for new resistant varieties. It is expected that the same phenomenon will be observed in Sarawak (Malaysian Borneo), which is a new 'rice bowl' state to increase rice production in Malaysia. Surveys from 2009 until 2012 in Sarawak showed that more than $50 \%$ of the surveyed rice field had moderate to high disease severity (Lai and Eng, 2011; Lai and Eng, 2013; Lai, 2016).

The knowledge on the genetic variations of $P$. oryzae could aid in managing rice blast disease. High genetic variations in a population will allow higher genetic recombination. Consequently, the breaking down of disease resistance will be rapid (Scheuermann et al., 2012). In Peninsular Malaysia, there are already four reports on the variations of $P$. oryzae (Abdul Rahim et al., 2013; Mat Muni and Nadarajah, 2014; Hasan et al., 2016; Abed-Ashtiani et al., 2016). Unfortunately, there is yet study on $P$. oryzae from Sarawak, neither their genetic variations nor pathogenicity. This paper provides a preliminary study on the variation of rice blast fungus isolated from selected rice fields in Sarawak based on their morphological characteristics.

\section{MATERIALS AND METHODS}

\section{Samples collection}

The rice blast infected leaf samples were collected from different rice fields (smallholders) in four different divisions in Sarawak: Miri, Kuching, Serian and Sri Aman during planting seasons of 2012 until 2016. Sampling points were decided based on the size of rice fields. In a one-hectare rice field, five sampling points were designated covering the field. If different rice landraces were planted by smallholders in one field, infected leaf samples were collected separately from each rice landrace.

\section{Fungal isolation}

Spore drop method modified from a method described by Choi et al. (1999) was used. Each rice blast lesion on an infected leaf was cut in half with each half of the lesion having a section of healthy part on one end. The specimens were surface sterilized with $1 \%$ commercial bleach $\left(\right.$ Clorox $\left.^{\circledR}\right)$ containing $5.25 \%$ sodium hypochlorite for 1 minute and rinsed 3 times with sterilized distilled water (each lesion was treated separately). Each piece of a lesion was then attached onto the upper-lid of a Petri dish containing water agar [WA; $2 \%$ agar (agar stick) w/v] with adaxial part facing towards the medium. Then, the plates were incubated in a humidity box at room temperature and observed daily for single spore colony of $P$. oryzae under a light microscope (ECLIPSE E100LED $M V R$ ). Each single spore colony was then picked and transferred onto oatmeal agar (OMA; $15 \mathrm{~g}$ of instant oatmeal and $7.5 \mathrm{~g}$ agar stick $/ 500 \mathrm{~mL}$ ). The plates were incubated under dark condition for 5 days and light condition for the subsequent days. Alternatively, if spores were observed on leaf segment but not on WA, the spores were dislodged with $250 \mu \mathrm{L}$ of sterilized distilled water and spread on a new plate of WA. It was then incubated under light condition at room temperature. Each single spore colony of $P$. oryzae was picked and cultured as described above.

\section{Molecular identification}

Universal primer pair Internal Transcribed Spacer (ITS)-1 (5'-TCCGTAGGTGAACCTGCGG-3') and -4 (5'TCCTCCGCTTATTGATATGC-3') was used for colony PCR (White et al., 1990). The PCR solution comprised of distilled water $\left(\mathrm{ddH}_{2} \mathrm{O}\right), 10 x$ PCR Buffer with $\mathrm{Mg}^{2+}$ (EasyTaq®), 25 mM MgCl 2,10 mM dNTPs, $10 \mu \mathrm{M}$ ITS-1 and ITS-4, Taq DNA Polymerase (EasyTaq $\left.{ }^{\circledR}\right)$, and pinch of young fungal mycelium (culture age ranged from 5 to 10 days ). PCR amplification was performed using $\mathrm{T}_{100}{ }^{\mathrm{TM}}$ Thermal Cycler (Bio-Rad Laboratories, USA) with the following profile: initial denaturation at $94^{\circ} \mathrm{C}$ for $2 \mathrm{~min}$; followed by 35 cycles of denaturation at $94^{\circ} \mathrm{C}$ for $30 \mathrm{sec}$, annealing at $50{ }^{\circ} \mathrm{C}$ for $30 \mathrm{sec}$, and extension at $72{ }^{\circ} \mathrm{C}$ for $1 \mathrm{~min}$; final extension at $72{ }^{\circ} \mathrm{C}$ for $5 \mathrm{~min}$. The PCR products were visualized on $1 \%$ agarose geland purified by using QIAquick ${ }^{\circledR}$ Gel Extraction Kit and sent for sequencing at Apical Scientific Sdn. Bhd. company. The sequences were used to blast (Blastn) against the sequences in gene bank (NCBI). The species verification was determined through percentage of identity and expectation value (E-value).

\section{Morphological characterization}

Morphological characterization method described by Mohammadpourlima et al. (2017) was adapted and modified. There were two types of media used for morphological characterization, viz, filtered oatmeal agar (FOMA; $15 \mathrm{~g}$ instant oatmeal and $7.5 \mathrm{~g}$ agar stick/500 ml) and potato dextrose agar (PDA; brand MERCK). FOMA was prepared in a similar manner as for OMA except that the oatmeal flakes and clumps were filtered out (for ease of scoring). Both media were then sterilized in an autoclave at 120 psi for $15 \mathrm{~min}$.

For all isolates, 10 days old cultures were used for subculture. An inoculum plug (5 $\mathrm{mm} \varnothing)$ was cut from the edge of actively growing mycelia and transferred (mycelium-side down) onto the center of a Petri dish containing $20 \mathrm{~mL}$ medium. For each medium, FOMA and PDA, there were ten replicates per isolate. The Petri dishes containing fungal plugs were then incubated in the dark for 5 days, followed with light condition for the subsequent days, at room temperature. Morphological characteristics of the colonies (form, elevation, margin, color and surface) were described (Microbiology, 2014.).

The colony growth was measured daily until the $10^{\text {th }}$ day and their growth rate was calculated. Then, sporulation rate was recorded for each isolate based on three randomly selected plates. Statistical analyses were 
carried out using SPSS software. ANOVA (analysis of variance) followed by Tukey HSD post hoc test was used to compare the difference in growth rate and sporulation rate between isolates in each medium at $p<0.05$ significance level. Mann-Whitney test was used to compare the growth rate and sporulation rate of each isolate on different media at $p<0.05$ significance level. This analysis excluded isolates POMI2, POSA3 and POS1 which did not produce spores on both media.

\section{RESULTS AND DISCUSSION}

\section{Isolation and identification}

In the rice fields of this study, the rice blast symptom (Figure 1a) observed on leaf was recognized as typical blast disease symptom, diamond shape with grayish center and brown margin (Wang et al., 2014). In total, there were 12 isolates of $P$. oryzae successfully isolated from four divisions (Table 1). There was one isolate from Miri, three from Serian as well as Sri Aman, and five from Kuching.

Preliminary identification of the isolates was done based on the morphology of spores before they were verified through molecular based method. The spores (Figure 1b) obtained were pear-shaped with narrowed apex and broad basal, hyaline in color, two septa and three celled. The spores were borne along the conidiophore (Figure 1c) with the basal of the spore attached at the tip of branches of conidiophore. In average, one conidiophore can hold more than 10 spores $(n=3)$.

The characteristics of the observed spores for 12 isolates obtained (Figure 2) were in agreement with descriptions from previous studies (Ou, 1987; TeBeest et al., 2007) and these characteristics allowed the preidentification of the different isolates as $P$. oryzae.

ITS amplification was successful for eight isolates (Table 2). The ITS amplicon size (bp) for the six isolates was approximately $500 \mathrm{bp}$, while for POK3 and POK4 isolates with the amplicon size (bp) of approximately 300 bp. BLASTn search verified the eight isolates as $P$. oryzae based on the percentage of identity and expectation value (E-value). The results (Table 2 ) showed
$99-100 \%$ of the query sequence homolog to the target sequence of $M$. oryzae in the database with E-value less than or equal to zero.

\section{Morphological characterization}

The morphological characteristics of all isolates are summarized in Table 3. The isolates were grouped based on morphological similarities (form, elevation, margin, and surface), excluding the criteria of color. There are 7 and 6 groups for FOMA and PDA, respectively.

The colony surface of the different isolates varied from smooth and fluffy to rough and flattened mycelia; some were with the presence of concentric rings, and some with aerial mycelia. All isolates showed raised elevation (viewed from side way) in both media except for three isolates (POMI2, POS1 and POSA3) which had raised elevation on one medium but flat elevation on the other. Despite of media used, all isolates had circular form and entire margin. The front colony was grey and light grey colored for most isolates on both media except for four isolates. While, the reverse colony was black colored for most isolates on both media except for three isolates (Table 3). The differences in morphology of the isolates in this study are similar to those reported by Srivastava et al. (2014) and Asfaha et al. (2015).

In short, morphological variations were observed among the 12 isolates from four different divisions. Such variations may suggest that the isolates were genetically different from each other. It might also be possible that the 12 isolates may have different pathogenicity capability. This assumption is based on the variations of dark pigmentation observed between the colony surface of the 12 isolates, and it has been reported that dark pigmentation correlates with pathogenicity (Lujan et al., 2016; Oh et al., 2017). The dark pigmentation of $P$. oryzae is crucial for the pathogen penetration into the host and to exhibit pathogenicity (Woloshuk et al., 1980; Chida and Sisler, 1987; Wheeler and Greenblatt, 1988). The correlation of pathogenicity with pigmentation intensity of $P$. oryzae could be an interesting area for further research.

The morphological variations of isolates from different

Table 1: The isolates of $P$. oryzae that were successfully isolated from different regions of Sarawak.

\begin{tabular}{|c|c|c|c|c|}
\hline Isolate & Location & Division & GPS & Rice Landrace \\
\hline POMI2 & Bario & Miri & N034'14.6”, E115²6'55.3" & Adan \\
\hline POS1 & Kg Remun, Tebedu & Serian & N0108'19.9", E110³9'02.9" & Biris \\
\hline POS2 & Kg Remun, Tebedu & Serian & N01ㅇㅇ'19.9", E110³9'02.9" & Bajong \\
\hline POS3 & Paon Gahat & Serian & N056'41.5”, E110³9'16.3" & Wangi \\
\hline POSA3 & Stumbin & Sri Aman & $\mathrm{N} 1^{\circ} 18^{\prime} 06.8^{\prime \prime}, \mathrm{E} 111^{\circ} 22^{\prime} 46.6^{\prime \prime}$ & Wangi Halus \\
\hline POSA1 & Stumbin & Sri Aman & $\mathrm{N} 1^{\circ} 18^{\prime} 06.8^{\prime \prime}, \mathrm{E} 111^{\circ} 22^{\prime} 46.6^{\prime \prime}$ & Unknown \\
\hline POSA2 & Sri Aman, Tg Bijat & Sri Aman & $\mathrm{N} 1^{\circ} 20^{\prime} 58.8^{\prime \prime}, \mathrm{E} 111^{\circ} 23^{\prime} 00.9^{\prime \prime}$ & Unknown \\
\hline POK2 & Senibong, Lundu & Kuching & N01 ${ }^{\circ} 35^{\prime} 48.0^{\prime \prime}, \mathrm{E} 109^{\circ} 53^{\prime} 22.2^{\prime \prime}$ & Unknown \\
\hline POK3 & Pueh, Sematan & Kuching & N0149'52.5", E10943'30.5" & Unknown \\
\hline POK4 & Siru Melayu, Sematan & Kuching & N0149'51.9", E10943'38.7" & Unknown \\
\hline POK5 & Siru Melayu, Sematan & Kuching & N0149'51.9", E10943'38.7" & Unknown \\
\hline POK6 & Kg Stunggang, Lundu & Kuching & N1॰38'58.9", E10951'15.9" & Unknown \\
\hline
\end{tabular}


Malays. J. Microbiol. Vol 16(1) 2020, pp. 58-67

DOI: http://dx.doi.org/10.21161/mjm.190423

Table 2: Summary of the BLASTn search results for ITS sequence of the $P$. oryzae isolates from this study.

\begin{tabular}{lccccc}
\hline Isolate & $\begin{array}{c}\text { Accession } \\
\text { number }\end{array}$ & Amplicon size (bp) & $\begin{array}{c}\text { Percentage of identity } \\
(\%)\end{array}$ & E-value & $\begin{array}{c}\text { Accession number } \\
(\mathrm{NCBI})\end{array}$ \\
\hline POSA2 & MK629260 & 490 & 99.59 & 0.0 & MH715386 \\
POK4 & NA & 314 & 100 & $7 \mathrm{e}-162$ & MH715393 \\
POK3 & NA & 290 & 100 & $1 \mathrm{e}-148$ & MH715373 \\
POSA1 & MK629259 & 489 & 99.59 & 0.0 & MF583110 \\
POS2 & MK629262 & 490 & 99.59 & 0.0 & MH715386 \\
POS1 & MK629264 & 491 & 99.59 & 0.0 & JX469384 \\
POM12 & MK629261 & 490 & 99.59 & 0.0 & MH715386 \\
POK6 & MK629263 & 490 & 99.59 & 0.0 & MH715386 \\
POK2 & NA & NA & NA & NA & NA \\
POS3 & NA & NA & NA & NA & NA \\
POSA3 $^{*}$ & NA & NA & NA & NA & NA \\
POK5 $^{*}$ & NA & NA & NA & & NA \\
\hline
\end{tabular}

* identified based on morphology of spores only

\# isolate with partial sequence

NA - not available

locations were random. There was no particular variation which is specific to one location that is the isolates with similar morphology were grouped differently despite the origin. For instance, the morphology of isolate POMI2 from Miri (northeastern Sarawak) was similar to that of an isolate from Serian division (southwestern Sarawak) on OMA. On PDA, the morphology of the Miri isolate was similar to three isolates originated from three different divisions in southwestern Sarawak, respectively. This finding agrees with that by Srivastava et al. (2014). However, this does not conclude that isolates from the same location are genetically unrelated, because positive correlation between molecular data and geographical origin of different isolates of $P$. orzyae was reported in Peninsular Malaysia (Abed-ashtiani et al., 2016).

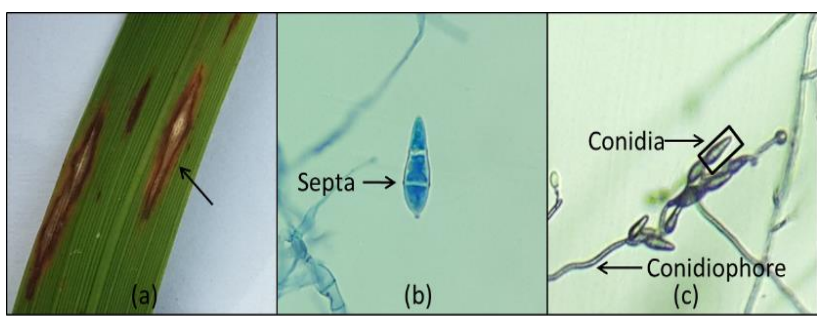

Figure 1: (a) The arrow points out the rice blast symptom, diamond shape with grayish center and brown margin (b) conidia (spore) (c) conidiophore.

\section{Growth rate and sporulation rate}

Growth rate and sporulation rate were tabulated in Table 4. Growth rate between isolates in each medium varied significantly. Isolate POS1 significantly had the fastest growth rate on FOMA with the mean value of 0.38 $\mathrm{cm}$ /day. On PDA, however, POS2 grew significantly faster than the other 11 isolates. Both isolates POS1 and POS2 were approximately $1 \frac{1}{2}$ days faster in growth as compared to isolate POS3 which was one of the slowest growing isolate on OMA and the slowest on PDA. Comparison of the growth rate of each isolate between the two media showed that seven isolates rapidly grew on PDA, and one isolate on FOMA. The results in this study are in agreement with that of Vanaraj et al. (2013).

Means of sporulation rate revealed the significant differences in sporulation between isolates on each medium. Isolate POS2 produced the highest number of spores on FOMA, whereas isolate POK6 produced the highest number of spores on PDA. Isolate POS3 produced the lowest amount of spores on both media. In general, most isolates seemed to be able to produce higher number of spores on FOMA as compared to PDA. Unfortunately, there was insufficient number of replicates per isolate for each medium to give a reliable statistical analysis.

There is a change in the ranking of isolates based on growth rate as well as sporulation rate on the two different media. This suggests that the physiological performance of an isolate may have been affected by the different media used. It was also observed in this study that there were very weak and moderate positive correlation between the pathogen growth rate and sporulation rate, $r$ $=0.03($ FOMA) and $r=0.65$ (PDA) respectively.

The morphological and physiological variations observed in this study may have associated with the nutrients present in each medium. FOMA was made from oat (Avena sp.), a close relative to rice, and it has been reported that oat is a host to $P$. grisea (Marangoni et al., 2013), a close relative to $P$. oryzae. The fact that isolates of $P$. oryzae exhibited different morphology, growth rate and sporulation rate on FOMA from PDA might suggest that oat contains comparable host material which is needed for $P$. oryzae for growth and sporulation.

The effect of the host material in the media can be seen in the induction of sporulation (Su et al., 2012), where all isolates (with sporulation) produced at least two times higher the number of spores on FOMA in comparison to PDA. Two of the isolates even produced four times higher the spore number on FOMA (no statistical evidence). The effect of media on sporulation of $P$. oryzae will be studied in the future. 
Malays. J. Microbiol. Vol 16(1) 2020, pp. 58-67

DOI: http://dx.doi.org/10.21161/mjm.190423

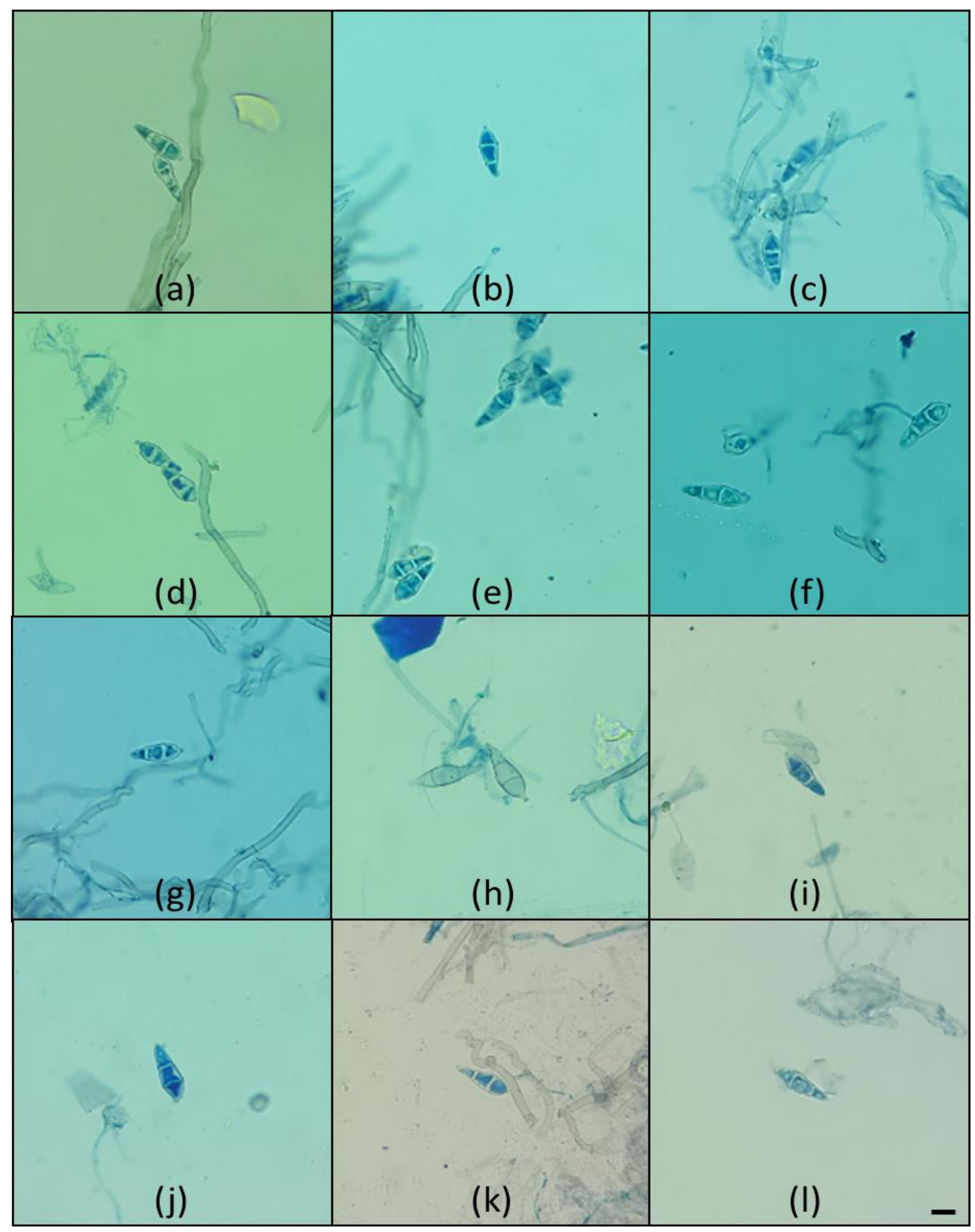

Figure 2: Spores of 12 isolates under light microscope at $40 \times$ magnification (a) POS2 (b) POSA1 (c) POK4 (d) POK5 (e) POK6 (f) POSA2 (g) POS3 (h) POMI2 (i) POK2 (j) POS1 (k) POSA3 (l) POK3. Scale bar, 10 $\mathrm{mm}$. 
Table 3: Summary of the morphological characteristics of $P$. oryzae on filtered oatmeal agar (FOMA) and potato dextrose agar (PDA).

\begin{tabular}{|c|c|c|c|c|c|c|c|}
\hline \multirow{2}{*}{ Media } & \multirow{2}{*}{ Group } & \multirow{2}{*}{ Isolate } & \multirow{2}{*}{ Division } & \multicolumn{2}{|c|}{ Color } & \multirow{2}{*}{ Elevation } & \multirow{2}{*}{ Surface description } \\
\hline & & & & Front & Reverse & & \\
\hline \multirow{12}{*}{ FOMA } & 1 & POS1 & Serian & $\begin{array}{l}\text { Olivace } \\
\text { ous } \\
\text { grey }\end{array}$ & Black & Flat & Smooth flattened mycelia \\
\hline & & POMI2 & Miri & $\begin{array}{l}\text { Light } \\
\text { brown }\end{array}$ & $\begin{array}{l}\text { Light } \\
\text { brown }\end{array}$ & & \\
\hline & & POS2 & Serian & Grey & Light grey & & Smooth fluffy mycelia at the \\
\hline & 2 & POK4 & Kuching & Grey & Black & Raised & center, flattened mycelia at the \\
\hline & & POK6 & Kuching & $\begin{array}{l}\text { Light } \\
\text { grey }\end{array}$ & $\begin{array}{l}\text { Light } \\
\text { brown }\end{array}$ & & \\
\hline & & POS3 & Serian & Grey & Black & & Smooth fluffy mycelia with \\
\hline & 3 & POK5 & Kuching & $\begin{array}{l}\text { Light } \\
\text { grey }\end{array}$ & Black & Raised & $\begin{array}{l}\text { concentric ring, flattened mycelia } \\
\text { after formation of ring }\end{array}$ \\
\hline & & POK3 & Kuching & Grey & Black & & \\
\hline & 4 & POSA1 & Sri Aman & $\begin{array}{l}\text { Olivace } \\
\text { ous } \\
\text { grey }\end{array}$ & Black & Raised & Smooth thinned mycelia \\
\hline & 5 & POK2 & Kuching & Grey & Black & Raised & $\begin{array}{l}\text { Smooth fluffy mycelia with white } \\
\text { aerial mycelia }\end{array}$ \\
\hline & 6 & POSA3 & Sri Aman & Grey & Black & Raised & Rough thinned mycelia \\
\hline & 7 & POSA2 & Sri Aman & Grey & Black & Raised & Smooth fluffy mycelia \\
\hline \multirow{11}{*}{ PDA } & 1 & POS1 & Serian & $\begin{array}{l}\text { Light } \\
\text { grey }\end{array}$ & Black & Raised & 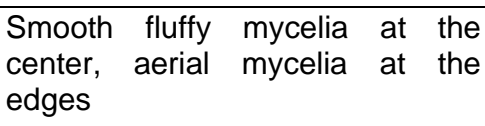 \\
\hline & \multirow[t]{3}{*}{2} & POSA2 & Sri Aman & Grey & Black & \multirow[t]{3}{*}{ Raised } & \multirow[t]{3}{*}{ Smooth fluffy mycelia } \\
\hline & & POK2 & Kuching & Grey & Black & & \\
\hline & & POS3 & Serian & Grey & Black & & \\
\hline & \multirow{3}{*}{3} & POSA1 & Sri Aman & Grey & Black & \multirow{3}{*}{ Raised } & \multirow{3}{*}{$\begin{array}{l}\text { Smooth fluffy mycelia at the } \\
\text { center, flattened mycelia at the } \\
\text { edges }\end{array}$} \\
\hline & & POK4 & Kuching & $\begin{array}{l}\text { Light } \\
\text { grey }\end{array}$ & Black & & \\
\hline & & POMI2 & Miri & $\begin{array}{l}\text { Light } \\
\text { grey }\end{array}$ & Black & & \\
\hline & \multirow{2}{*}{4} & POs2 & Serian & Grey & Black & \multirow{2}{*}{ Raised } & \multirow{2}{*}{$\begin{array}{l}\text { Smooth fluffy mycelia at the } \\
\text { center with concentric ring, aerial } \\
\text { mycelia after formation of ring }\end{array}$} \\
\hline & & POK3 & Kuching & Grey & Black & & \\
\hline & 5 & $\begin{array}{l}\text { POK5 } \\
\text { POK6 }\end{array}$ & $\begin{array}{l}\text { Kuching } \\
\text { Kuching }\end{array}$ & $\begin{array}{l}\text { Grey } \\
\text { Light } \\
\text { grey }\end{array}$ & Black & Raised & $\begin{array}{l}\text { Aerial mycelia with concentric } \\
\text { rings }\end{array}$ \\
\hline & 6 & POSA3 & Sri Aman & $\begin{array}{l}\text { Light } \\
\text { brown }\end{array}$ & Black & Flat & Smooth flattened mycelia \\
\hline
\end{tabular}

Note: Form and margin for all isolates are circular and entire respectively. 
Malays. J. Microbiol. Vol 16(1) 2020, pp. 58-67

DOI: http://dx.doi.org/10.21161/mjm.190423

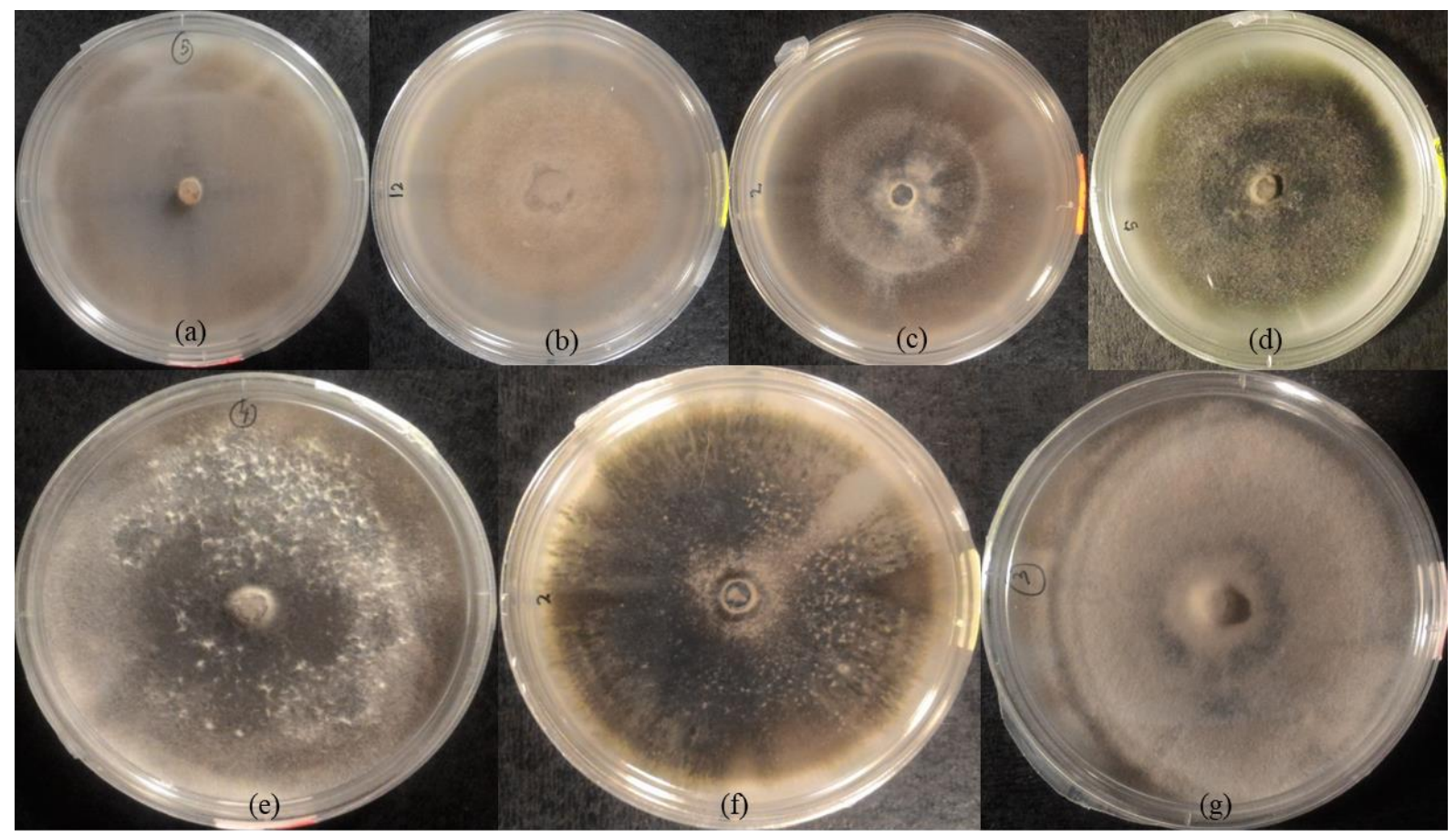

Figure 3: Colony morphology of isolates on FOMA based on groups; (a-g) represent isolates from group 1 to 7.

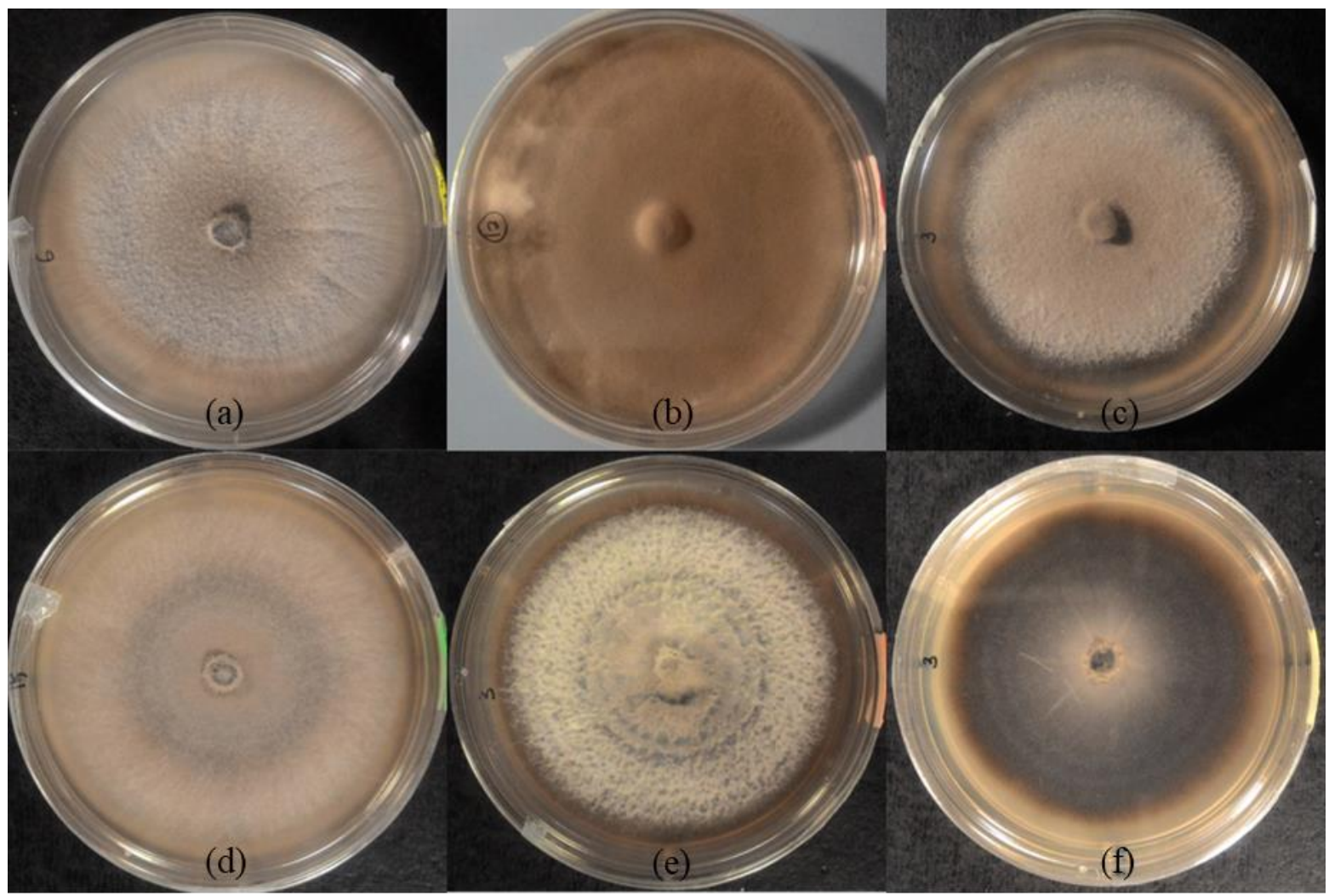

Figure 4: Colony morphology of isolates on PDA based on group; (a-f) represent isolates from group 1 to 6. 
Table 4: Growth rate and sporulation rate of different isolates on two types of media: FOMA, and PDA.

\begin{tabular}{lcccccccc}
\hline & \multicolumn{3}{c}{ Growth rate (cm/day) } & \multicolumn{3}{c}{$\begin{array}{c}\text { Sporulation rate }\left(10^{5}\right) \text { in } \\
\text { ImL of spore suspension }\end{array}$} \\
\cline { 2 - 9 } & FOMA & $\begin{array}{c}\text { Standard } \\
\text { error }\end{array}$ & PDA & $\begin{array}{c}\text { Standard } \\
\text { error }\end{array}$ & FOMA & $\begin{array}{c}\text { Standard } \\
\text { error }\end{array}$ & $\begin{array}{c}\text { PDA } \\
\text { Standard } \\
\text { error }\end{array}$ \\
\cline { 2 - 9 } POS3 & $0.32^{\mathrm{a}}$ & \pm 0.0030 & $0.33^{\mathrm{a}}$ & \pm 0.0045 & $0.33^{\mathrm{a}}$ & \pm 0.0629 & $0.15^{\mathrm{a}}$ & \pm 0.0382 \\
POSA2 & $0.32^{\mathrm{a}}$ & \pm 0.0015 & $0.37^{\text {def }}$ & \pm 0.0012 & $1.24^{\mathrm{ab}}$ & \pm 0.0333 & $0.31^{\mathrm{a}}$ & \pm 0.0315 \\
POK5 & $0.33^{\mathrm{ab}}$ & \pm 0.0018 & $0.36^{\mathrm{bcd}}$ & \pm 0.0014 & $0.43^{\mathrm{a}}$ & \pm 0.1797 & $0.16^{\mathrm{a}}$ & \pm 0.0042 \\
POSA1 & $0.34^{\mathrm{bc}}$ & \pm 0.0025 & $0.36^{\mathrm{bc}}$ & \pm 0.0020 & $0.59^{\mathrm{a}}$ & \pm 0.0402 & $0.23^{\mathrm{a}}$ & \pm 0.0315 \\
POK4 & $0.34^{\mathrm{cd}}$ & \pm 0.0054 & $0.39^{\mathrm{f}}$ & \pm 0.0011 & $2.63^{\mathrm{c}}$ & \pm 0.3403 & $1.39^{\mathrm{c}}$ & \pm 0.0629 \\
POK3 & $0.36^{\mathrm{de}}$ & \pm 0.0039 & $0.36^{\mathrm{bcd}}$ & \pm 0.0040 & $2.08^{\mathrm{bc}}$ & \pm 0.1585 & $0.95^{\mathrm{b}}$ & \pm 0.0870 \\
POMI2 & $0.36^{\mathrm{e}}$ & \pm 0.0010 & $0.35^{\mathrm{b}}$ & \pm 0.0014 & 0.00 & - & 0.00 & - \\
POK2 & $0.36^{\mathrm{e}}$ & \pm 0.0017 & $0.36^{\mathrm{bcd}}$ & \pm 0.0021 & $0.56^{\mathrm{a}}$ & \pm 0.0696 & $0.24^{\mathrm{a}}$ & \pm 0.0217 \\
POS2 & $0.36^{\mathrm{e}}$ & \pm 0.0010 & $0.44^{\mathrm{h}}$ & \pm 0.0015 & $6.22^{\mathrm{d}}$ & \pm 0.9813 & $1.35^{\mathrm{c}}$ & \pm 0.0723 \\
POSA3 & $0.37^{\mathrm{e}}$ & \pm 0.0018 & $0.37^{\mathrm{cde}}$ & \pm 0.0014 & 0.00 & - & 0.00 & - \\
POK6 & $0.37^{\mathrm{e}}$ & \pm 0.0030 & $0.42^{\mathrm{g}}$ & \pm 0.0041 & $3.08^{\mathrm{c}}$ & \pm 0.1630 & $1.44^{\mathrm{c}}$ & \pm 0.1740 \\
POS1 & $0.38^{\mathrm{f}}$ & \pm 0.0014 & $0.38^{\mathrm{ef}}$ & \pm 0.0042 & 0.00 & - & 0.00 & - \\
\hline
\end{tabular}

Note: ANOVA followed by Tukey HSD post hoc test was used to compare the difference in growth rate and sporulation rate between isolates in each media $(p<0.05)$. The same alphabet within column indicates the variances do not differ significantly. Mann-Whitney test was used to compare the growth rate of each isolate on the two media. Bold font indicates significant different in growth rate on the different media for each isolate.

\section{CONCLUSION}

In conclusion, 12 isolates were successfully isolated from infected leaves through spore drop isolation method. This preliminary study showed that there were variations observed based on morphological characters for the different isolates collected in Sarawak, Malaysian Borneo. There were no morphological characters unique to a specific location. The growth rate and sporulation rate of the different isolates varied on different media. This study is the first step towards understanding variations in the population of $P$. oryzae from Sarawak. It would be interesting to isolate more $P$. oryzae from different locations to have a better representation of the population. Further study on the genetic variations and pathogenicity are also significant.

\section{ACKNOWLEDGEMENTS}

This project is supported by Research Acculturation Grant Scheme from Malaysia Ministry of Education, Grant No: RAGS/WAB01(1)/1319/2015(13). The authors would like to acknowledge Faculty of Resource Science and Technology, UNIMAS for the facilities provided. We would also like to show our gratitude to Mdm Chyale ak Rabe, $\mathrm{Mr}$ Johari bin Julaihi and Mr Maurice Kebing for the assistance provided during this study.

\section{REFERENCES}

Ashkani, S., Rafii, M. Y., Shabanimofrad, M., Miah, G., Sahebi, M., Azizi, P., Tanweer, F. A., Akhtar, M. S. and Nasehi, A. (2015). Molecular breeding strategy and challenges towards improvement of blast disease resistance in rice crop. Frontiers in Plant Science 6(886), 1-14.

Abdul Rahim, F. H., Hawari, N. N. and Zainal Abidin, N. (2017). Supply and demand of rice in Malaysia: A system dynamics approach. International Journal of Supply Chain Management 6(4), 1-7.

Abdul Rahim, H., Bhuiyan, M. A. R., Saad, A., Azhar, M. and Wickneswari, R. (2013). Identification of virulent pathotypes causing rice blast disease (Magnaporthe oryzae) and study on single nuclear gene inheritance of blast resistance in $F_{2}$ population derived from Pongsu Seribu $2 \times$ Mahsuri. Australian Journal of Crop Science 7(11), 1597-1605.

Abed-Ashtiani, F., Kadir, J., Nasehi, A., HashemianRahaghi, S., Vadamalai, G. and Rambe, S. (2016). Characterisation of Magnaporthe oryzae isolates from rice in peninsular Malaysia. Czech Journal of Genetics and Plant Breeding 52(4), 145-156.

Asfaha, M. G., Selvaraj, T. and Woldeab, G. (2015). Assessment of disease intensity and isolates characterization of blast disease (Pyricularia oryzae CAV.) from South West of Ethiopia. International Journal of Life Sciences 3(4), 271-286.

Chida, T. and Sisler, H. D. (1987). Restoration of appresorial penetration ability by melanin precursors in Pyricularia oryzae treated with anti penetrants and in melanin-deficient mutants. Journal of Pesticide Science 12, 49-55.

Choi, Y. W., Hyde, K. D. and Ho, W. W. H. (1999). Single spore isolation of fungi. Fungal Diversity 3, 2938. 
Elixon, S., Asfaliza, R., Othman, O., Siti Norsuha, M., Maisarah, M. S., Allicia, J. and Shahida, H. (2017). Evaluation on yield, yield component and physicchemicals of advanced rice lines. Journal of Tropical Agriculture and Food Science 45(2), 131-143.

Gianessi, L. P. (2014). Importance of pesticides for growing rice in South and South East Asia. CropLife Foundation 1-4.

Global Rice Science Partnership. (2013). Rice almanac. $4^{\text {th }}$ edition. Los Banos (Philippines): International Rice Research Institute. pp. 1-283.

Hasan, N. A., Rafii, M. Y., A.Rahim, H., Syd Ali, N., Mazlan, N. and Abdullah, S. (2016). Morphological and molecular characterization of fungal pathogen, Magnaporthe oryzae. AIP Conference Proceedings 1705, 020015-1-5.

Hussain, Z. P. M. D., Mokhtar, A., Amzah, B., Hashim, M. and Ghafar, M. B. A. (2012). Enam variety padi popular MARDI. Buletin Teknologi MARDI 1, 1-10.

Khush, G. S. (2005). What it will take to feed 5.0 billion rice consumers in 2030. Plant Molecular Biology 59, 1-6.

Lai, L. S. and Eng, L. (2013). Prevalence and incidence of paddy blast disease in Sarawak in 2012. Research Officers' Conference, 1-3 October 2013. Department of Agriculture Sarawak.

Lai, L. S. and Eng, L. (2011). Prevalence and severity of paddy blast disease in Sarawak 2009-2010. In: Proc. Research Officers' Progress Meeting, 4-6 October 2011, Department of Agriculture Sarawak (poster presentation).

Lai, L. S. (2016). Blast disease and the screening on selected rice varieties. Proc. Technical Session, Senior Officers' Conference, 25-27 Oct. 2016. Department of Agriculture Sarawak.

Lujan, P., Sanogo, S., Puppala, N. and Randall, J. (2016). Factors affecting mycelium pigmentation and pathogenicity of Sclerotinia sclerotiorum on Valencia peanut. Canadian Journal of Plant Science 96, 461473.

Marangoni, M. S., Nunes, M. P., Fonseca, J. N. and Mehta, Y. R. (2013). Pyricularia blast on white oats a new threat to wheat cultivation. Tropical Plant Pathology 38(3), 198-202.

Microbiology (2014). Morphology and general properties of fungi. https://nios.ac.in/media/documents /dmlt/Microbiology/Lesson-51.pdf [Retrieved on 20 November 2016].

Mohammadpourlima, M., Yassoralipour, A., Tong, P. E., Ahmad, Z. A. M. and Yun, W. M. (2017). Morphological and molecular characterizations of rice blast fungus, Magnaporthe oryzae. Pakistan Journal of Agricultural Sciences 54(4), 785-792.

Muni, N. M. and Nadarajah, K. (2014). Morphological and molecular characterization of Magnaporthe oryzae (fungus) from infected rice leaf samples. AIP Conference Proceedings 1614, 756-760.

Ou, S. H. (1987). Rice diseases. Slough SL2 3BN, UK: C.A.B International. pp. 115-121.
Oh, Y., Robertson, S. L., Parker, J., Muddiman, D. C. and Dean, R. A. (2017). Comparative proteomic analysis between nitrogen supplemented and starved conditions in Magnaporthe oryzae. Proteome Science 15(20), 1-12.

Scheuermann, K. K., Raimondi, J. V., Marschalek, R., de Andrade, A. and Wickert, E. (2012). Magnaporthe oryzae genetic diversity and its outcomes on the search for durable resistance. In: The Molecular Basis of Plant Genetic Diversity. Caliskan, M. (ed.). InTech. pp. 331-356.

Silva, G. B., Prabhu, A. S., Filippi, M. C. C., Trindade, M. G., Araujo, L. G. and Zambolim, L. (2009). Genetic and phenotypic diversity of Magnaporthe oryzae from leaves and panicles of rice in commercial fields in the state of Goias, Brazil. Tropical Plant Pathology 34(2), 71-76.

Skamnioti, P. and Gurr, S. J. (2009). Against the grain: safeguarding rice from rice blast disease. Trends in Biotechnology 27(3), 141-150.

Srivastava, D., Shamim, M., Kumar, D., Pandey, P., Khan, N. A. and Singh, K. N. (2014). Morphological and molecular characterization of Pyricularia oryzae causing blast disease in rice (Oryza Sativa) from North India. International Journal of Scientific and Research Publications 4(7), 1-9.

Su, Y., Qi, Y. and Cai, L. (2012). Induction of sporulation in plant pathogenic fungi. Mycology 3(3), 195-200.

TeBeest, D. O., Guerber, C. and Ditmore, M. (2007). Rice blast. Available from The American Phytopathological Society website https://www.apsnet.org/edcenter/disandpath/fungalasc o/pdlessons/Pages/RiceBlast.aspx [Retrieved on 02 February 2019].

Talbot, N. J. and Wilson, R. A. (2009). Under pressure: Investigating the biology of plant infection by Magnaporthe oryza. Nature Reviews: Microbiology 7, 185-195.

Vanaraj, P., Kandasamy, S., Ambalavanan, S., Ramalingam, R. and Sabariyappan, R. (2013). Variability in Pyricularia oryzae from different rice growing regions of Tamil Nadu, India. African Journal of Microbiology Research 7(26), 3379-3388.

Wang, X., Lee, S., Wang, J., Ma, J., Bianco, T. and Jia, Y. (2014). Current advances on genetic resistance to rice blast disease. In: Rice - Germplasm, Genetics and Improvement. Yan, W. and Bao, J. (eds). InTech. pp. 195-217.

White, T. J., Bruns, T. and Taylor, J. (1990). Amplification and direct sequencing of fungal ribosomal RNA genes for phylogenetics. In: PCR protocols - A guide to methods and applications. Innis, M. A., Gelfand, D. H., Sninsky, J. J. and White, T. J. (eds). Academic Press. pp. 315-322.

Woloshuk, C. P., Sisler, H. D., Tokousbalides, M. C. and Dutky, S. R. (1980). Melanin biosynthesis in Pyricularia oryzae: Site of tricyclazole inhibition and pathogenicity of melanin-deficient mutants. Pesticide Biochemistry and Physiology 14, 256-264. 
Malays. J. Microbiol. Vol 16(1) 2020, pp. 58-67

DOI: http://dx.doi.org/10.21161/mjm.190423

Wheeler, M. H. and Greenblatt, G. A. (1988). The inhibition of melanin biosynthetic reactions in Pyricularia oryzae by compounds that prevent rice blast disease. Experimental Mycology 12, 151-160.

Zhou, J. (2016). Plant pathology: A life and death struggle in rice blast disease. Current Biology Dispatches 26(18), 843-845. 